\title{
Does privatization make Brazilian airports more efficient?
}

\author{
A privatização torna os aeroportos brasileiros mais eficientes?
}

\section{Fernanda Silva Toledo ${ }^{1}$, Viviane Adriano Falcão², Flávia de Castro Camioto ${ }^{3}$, Paulo Afonso Lopes da Silva ${ }^{4}$}

${ }^{1}$ Federal University of Rio de Janeiro, Rio de Janeiro - Brazil, fernanda.toledo@coc.ufrj.br

${ }^{2}$ Federal University of Pernambuco, Pernambuco - Brazil, viviane.afalcao@ufpe.br

3Federal University of Triângulo Mineiro, Minas Gerais-Brazil, flaviacamioto@yahoo.com.br

${ }^{4}$ Military Institute of Engineering, Rio de Janeiro - Brazil, pauloafonsolopes@uol.com.br

\section{Recebido: \\ 14 de fevereiro de 2020 \\ Aceito para publicação: \\ 5 de fevereiro de 2021 \\ Publicado: \\ 25 de agosto de 2021 \\ Editor de área: \\ Alexandre Gomes de Barros}

\section{Keywords:}

Airports Privatization.

Data Analysis Envelopment.

Tobit Regression.

Airport efficiency.

SBM.

Airport Infrastructure.

Palavras-chave:

Concessões.

Aeroportos.

DEA.

SBM

Regressão Tobit.

DOI:10.14295/transportes.v29i2.2304

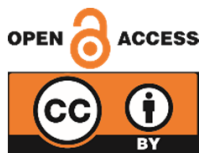

\section{ABSTRACT}

Airport concessions to private management began in Brazil in 2011 to address infrastructure bottlenecks and the need for investments. Productivity improvements after privatization need to be measured and efficiency gains can help to identify strategic points where to intervene both in current and upcoming concessions. However, previous studies have applied neither the Slacks-Based Measure Data Analysis Envelopment models nor the second stage Tobit regression to evaluate airport efficiency, especially in the context of Brazilian airport privatization. The objective of this study is to verify if privatization contributes to improving Brazilian airports' productive efficiency compared with public airports, using variable slacks and identifying new socio-economic variables that may influence the productive efficiency index. A two-stage SBM-DEA approach found that only $40 \%$ of the sample among 28 airports are efficient, evidencing poor management overall, and the slacks show the sectors that need most attention and investments. Based on the productive process and the sample evaluated, the study concludes that privatization of Brazilian airports did not improve their production efficiency. A revision of the contracts in the first round of concessions is suggested, as contractual obligation may result in lower production efficiency.

\section{RESUMO}

As concessões dos aeroportos à gestão privada começaram no Brasil em 2011 para resolver gargalos de infraestrutura e a necessidade de investimentos. Melhorias de produtividade após a privatização precisam ser medidas e os ganhos de eficiência podem ajudar a identificar pontos estratégicos em que intervir tanto nas concessões atuais quanto nas futuras. É notório na literatura estudos que aplicaram DEA para medir a eficiência aeroportuária. No entanto, estudos anteriores não aplicaram os modelos SlacksBased Measure Data Analysis Envelopment nem a regressão Tobit de segundo estágio para avaliar a eficiência aeroportuária, especialmente no contexto da privatização de aeroportos brasileiros. $\mathrm{O}$ objetivo deste estudo é verificar se a privatização contribui para melhorar a eficiência produtiva dos aeroportos brasileiros em relação aos aeroportos públicos, utilizando folgas nas variáveis e identificando novas variáveis socioeconômicas que podem influenciar o índice de eficiência produtiva. Uma abordagem SBMDEA em dois estágios constatou que apenas $40 \%$ da amostra, dentre 28 aeroportos, são eficientes, evidenciando uma má gestão no geral, e as folgas mostram os setores que precisam de mais atenção e investimentos. Com base no processo produtivo e na amostra avaliada, o estudo conclui que a privatização dos aeroportos brasileiros não melhorou sua eficiência produtiva. Sugere-se a revisão dos contratos da primeira rodada de concessões, pois a obrigatoriedade contratual pode resultar em menor eficiência produtiva. 


\section{INTRODUCTION}

Brazilian air transportation has experienced a fast growth in demand in the last few decades, which led to higher demand for infrastructure. In this scenario, the Brazilian government transferred in concession some of the main Brazilian airports to the private sector to accelerate and allow for modernization of facilities, investments in infrastructure, and technological innovations. The investments required would improve productivity and service quality (INFRAERO, 2016), but the main problem is airport operational inefficiency and how the effect of privatization is evaluated in these terms.

Airport concessions started in Brazil in 2011. To date, 22 airports have been privatized and 22 public airports are in the National Program for Concessions to be transferred in 2021.

The performance assessment is crucial to evaluate the demand adequacy and to evaluate the results of the current concessions and the upcoming ones in airport productivity considering that privatization of airports in Brazil was carried out following the concession model. Although the main purpose to privatize an airport is to improve its efficiency, there is no evidence of performance benefits (Graham, 2011). In the case of Brazil, the concessions are the result of restrictions on public investments considering a greater flexibility of private investments.

The objective of this paper is to verify if Brazilian airport concessions lead to the improvement of the production efficiency of the privatized airports, evaluating their efficiency index and variable slacks and considering their operational aspects. The Slack-Based Measurement (SBM) model is used to measure efficiency scores and identify ways for the inefficient units to reach the efficiency frontier based on the slacks in each variable, to obtain the ranking position of the airports granted in concession, the country overall scenario and the influence of macro and socioeconomic variables in the efficiency in a second stage Tobit regression.

Ownership of airports is one of the most studied factors to explain efficiency, but a consensus has not been found yet (Iyer and Jain, 2019). Thus, research is still required to clarify this effect (Carlucci et al., 2018; Lo Storto, 2018). On the other hand, considering the economic crisis in Brazil since 2014, despite optimistic demand projections for large investments - mandated by a concession contract -losses are to be expected in the upcoming years. Therefore, the investments should be directed to areas that need them the most, so the existing resources can be used optimally.

Data Envelopment Analysis (DEA) is a technique to measure efficiency through a production frontier based on linear programming. It has the advantage of computing multiple inputs and outputs at the same time, measuring a relative efficiency among samples. Several studies have applied DEA to evaluate the operational efficiency of airports in Argentina (Barros, 2008), Asia and Pacific (Tsui et al., 2014), China (Jiang et al., 2015), Italy (Carlucci et al., 2018), United States (Bazargan and Vasigh, 2003), and Turkey (Örkcü et al., 2016). Generally, studies are limited to mathematical models with either constant or variable returns to scale using only input or output orientation. Some studies include airports' details and characteristics to develop a new model (Bazargan and Vasigh, 2003; Chang et al., 2016; Olfat et al., 2016), which is the main difficulty in DEA application, or use distance minimization methods (Suzuki et al., 2012). The Slack-Based Measure (SBM-DEA) was used in a weighted form in European and Australian airports, and in a fuzzy extension of SBM dynamic network approach (Olfat et al., 2016) to study 
the variation of efficiency determined by variables related to internal airport functions which affect community and are related to passengers.

This paper focusses on the slacks of each variable, besides the efficiency index, to identify points to improve management. This proposition aims to fulfill the research gap (Iyer and Jain, 2019) on the application of efficiency scores to improve airport performance because the use of performance assessment by airport authorities to monitor individual airports was not fully explored (Iyer and Jain, 2019).

Brazilian airports have been studied using bootstrap DEA (developed by Simar and Wilson, 1998) to measure their operational efficiency (Périco et al., 2017), or network DEA (Wanke, 2013), but no studies have used slack-based measure, especially in the context of privatization. Fernandes and Pacheco (2018) applied the Malmquist Index and variable returns to scale (BCC) output-oriented model to evaluate the performance of public airports under INFRAERO management.

In this paper, we used SBM-DEA with simultaneous orientation (both to input and output), which allowed the model to consider both the product increase and the reduction of the resources to form the efficient frontier, an advantageous analysis within the current context of economic and political crisis in Brazil. As far as the authors know, the SBM model (developed by Tone, 2001) has not yet been applied to the airport infrastructure in the non-oriented form.

Furthermore, this model, as non-radial (Constant and Mello, 2017), permits to identify the optimal increase or decrease in each variable separately, to achieve the efficiency frontier and not a simple change of equal proportion of all the inputs or outputs, as proposed by classic models, like CCR (Charnes, Cooper and Rhodes, 1978) and BCC (Banker, Charnes and Cooper, 1984).

Therefore, this paper applies an existing technique in a new way and aims to throw some new light on their applicability in the airport infrastructure domain. So, it is possible to identify which aspects make an airport inefficient, not only looking at the input or output, but also to both.

Measuring airport efficiency is important for both the companies and the Brazilian State to understand the requirements and saturation of each airport. Furthermore, it is substantial to evaluate the airports granted in concessions in their role of fulfilling required investments and maintaining the airport operational efficiency.

A second stage analysis is an option to explain DEA results, as the environmental aspects do not take part in the score and the results are deterministic among the variables used. The second stage approach usually applies a simple regression, truncated regression, or bootstrapping. In this study, we used an Inverted Frontier (Soares de Mello et al., 2008) to increase discrimination in the efficiency frontier and a Tobit regression to investigate the effects of macroeconomic and socioeconomic variables.

The use of a model that proposes a reduction of resources to reach efficiency, does not mean to encourage the reduction of investments in airports. Therefore, this article aims to identify the underused sectors that could have their capacity used in an optimum way and adapt resources from different activities to a new section or saturated sector. This paper focus on productive efficiency especially throughout an economic crisis, when the resources are scarce, an approach applicable to a broad range of settings and organizations. Also, the study aims to spread the knowledge of using this method in a non-obvious way. 


\section{DATA ENVELOPMENT ANALYSIS}

Data Envelopment Analysis (DEA) is a technique used to measure the productivity of business units, proposed by Charnes et al. (1978) and Banker et al. (1984), both based on Farrel (1957). DEA is based on non-parametric linear programming, therefore there is no predefined function of the input-output-efficiency relationship. This technique comprises data of each variable to establish an efficiency frontier composed by units in which it is not possible to benefit one more characteristic without demeaning the others, called the Pareto-Efficient (Wanke et al., 2009, Camioto et al., 2016). This technique identifies the most efficient units in a sample and computes a measure of inefficiency for the other Decision-Making Units (DMUs). Therefore, it does not find an absolute efficiency but compares the productive units to each other considering the inputs used and the products generated (Wanke et al., 2009; Falcão and Correia, 2012).

The constant returns to scale (CCR) model, based on the contributions of Charles, Cooper, and Rhodes (1978), generates a frontier of constant return to scale. Therefore, any input variation produces a proportional variation of outputs.

If there are $n$ DMUs under analysis, each $D M U_{j}$ consumes a variable quantity of each input to generate different outputs. The result is $h_{j}$, a number between 0 and 1 that represents the relative efficiency of each DMU.

The model can be output-oriented when the objective is to maximize outputs for each DMU without changing the current inputs, or input-oriented to minimize the resources until the current outputs are not reduced (Mariano et al., 2015). In that case, for the CCR model, the orientation does not influence the measure of efficiency since the return of scale is constant.

The Banker, Charles, and Cooper (1984) model (BCC) uses a more realistic premise based on a convexity constant $\sum_{j=1}^{n} \lambda_{j}=1$, which modifies the straight line of the frontier to a convex cone (WANKE et al., 2009). For that reason, the BCC model replaces the proportionality of the CCR inducing a convex frontier, which allows variable returns to scale (Mariano et al., 2015).

\subsection{DEA Model - SBM}

With a close connection between CCR and BCC models, the SBM (Slack-Based Measure) model deals directly with an excess of input and output deficits of the decision-making units. First proposed by Tone (2001), SBM-DEA allows simultaneous orientation to input and output, minimizing the distances to reach the efficiency frontier.

Tone (2001) also revealed that, unlike the CCR model, the DEA-SBM model seeks the maximum virtual profit, with results based on radial measures. The comparison between the two models reveals that the SBM generally computes lower efficiency values, due to the existence of slacks and the fact that all variables contribute to the efficiency evaluation, even at lower levels. Other models allow null weights to exclude the contribution of variables that would lead to a decrease in the scalar efficiency (Tone, 2001).

The following expressions identify the SBM model with variable returns according to Tone (2001):

$$
\operatorname{Min} \tau=t-(1 / n) \sum_{j=1}^{n} S_{j} / x_{j 0}
$$

Subject to:

$$
\frac{1}{m} \sum_{i=1}^{m} S_{i} / y_{i 0}+t=1
$$




$$
\begin{aligned}
& \sum_{k=1}^{Z} x_{j k} \cdot \lambda_{k}+S_{j}-t \cdot x_{j 0}=0, \text { for } j=1,2 \ldots n \\
& \sum_{k=1}^{Z} y_{i k} \cdot \lambda_{k}-S_{i}-t \cdot y_{j 0}=0, \text { for } j=1,2 \ldots m \\
& \sum_{k=1}^{Z} \lambda_{k}=t \\
& \lambda_{k}, S_{j} \text { e } S_{i} \geq 0 \text { e } t>0
\end{aligned}
$$

in which $\quad \lambda_{k}$ : DMU k participation in the target DMU under analysis;

$x_{j k}: \quad$ Quantity of input j of the DMU k;

$y_{i k}: \quad$ Quantity of output i of the DMU k;

$x_{j 0}$ : $\quad$ Quantity of input $\mathrm{j}$ of the DMU under analysis;

$y_{i 0}$ : $\quad$ Quantity of output i of the DMU under analysis;

$z: \quad$ Number of units under evaluation;

$m: \quad$ Number of outputs;

$n: \quad$ Number of inputs;

$S_{i}$ : $\quad$ Slacks variable of output i;

$S_{j}: \quad$ Slacks variable of input j;

$t$ : $\quad$ Linear adjustment variable.

In addition to measuring the relative efficiency of DMUs, this method also allows us to compute the slacks, which express by how much each DMU should increase the value of each variable to achieve efficiency. Thus, slacks indicate how far the current performance of a DMU is from its ideal performance for each variable, where the ideal performance is a target symbolized by a virtual DMU (benchmark), located at the efficiency frontier and calculated according to the expressions:

$$
\begin{aligned}
\text { Target Input } & =x_{j 0}-S_{j}, \text { for } i=1,2,3 \ldots n \\
\text { Target Output } & =y_{i 0}+S_{i} \text { for } i=1,2,3 \ldots m
\end{aligned}
$$

Given that the relative slack is based both on the current and the ideal performances, it is expressed by the percentage of improvement required of each variable.

\subsection{Tobit Regression}

Econometric models with censored error or truncated terms are normally used for dependent variables that have specific limits, as is the case of the efficiency index whose value is comprised between 0 and 1 . The Tobit model devised by Tobin (1958) is normally used in these situations, where the dependent variable has a limiting value such as zero. In this case, the Tobit stochastic model may be expressed by the equations (McDonald \& Moffitt, 1980):

$$
\begin{gathered}
y_{t}=x_{t} \beta+u_{t} \text { if } X_{t} \beta+u_{t}>0 \\
y_{t}=0 \text { if } X_{t} \beta+u_{t} \leq 0, \\
\mathrm{t}=1,2, \ldots, \mathrm{N},
\end{gathered}
$$

where $\mathrm{N}$ represents the number of observations, $y_{t}$ the dependent variable, $X_{t}$ is a vector of independent variables, $\beta$ is a coefficient vector and $u_{t}$ is an independently distributed error term, which is assumed to be normally distributed with zero mean and variance $\sigma^{2}$.

The model assumes a stochastic index equal $x_{t} \beta+u_{t}$ only when the result is positive, which certifies it as an unobserved latent variable. The use of this model may indicate the relationship between macroeconomic and socioeconomic variables that influence airport efficiency.

\subsection{DEA APPLIED TO AIRPORTS}

The Data Envelopment Analysis (DEA) technique has been applied to airports by several studies 
such as Barros (2008) to estimate the technical efficiency of airports impacted by a reduction of 50\% of air traffic in Argentina from 2003 to 2007, a period of an intense economic crisis. Despite the economic crisis and visible changes in output variables in the years under review, some airports remained efficient. Relatively efficient airports started the period as inefficient but recovered in the end to achieve their best practices, showing that the larger airports remained immune to the crisis, while smaller and regional ones were more sensitive to it.

Tsui et al. (2014) investigated the operational efficiency of 21 airports in Asia and in the Pacific, with data covering the years from 2002 to 2011, in a window analysis. They suggested that the variation in airport efficiency could be explained by the percentage of international passengers' traffic, the number of airport employees, dominant airlines, and per capita GDP growth.

Jiang et al. (2015) conducted a study covering 9 Chinese airports. On the coastal region of the country, the density of civil airports reached one per city, but large-scale airports were supersaturated while medium and minor ones operated in deficit, suggesting an airport alliance as a solution to the survival of the medium and small ones.

The operational and financial performance of Italian airports were studied by Barros and Dieke (2011) using data from 2001 to 2003 and a BCC model to identify management skills. As a result, the performance of airports under private initiative had higher rates.

Merkert and Mangia (2014) focused on the cost efficiency of Italian and Norwegian airports. For regional and small airports, the level of competitiveness impacts airport efficiency, while airports in full concession are more efficient than airports with partial concessions.

For the US airports grouped by size, Bazargan and Vasigh (2003) used financial and operational data to identify inefficient airports that are dominated by the most efficient ones.

Örkcü et al. (2016) assessed the operational efficiency of Turkish airports, they identified a decline in efficiency due to the increase in the physical capacity of airports and the non-reflection of this increase on passenger and cargo traffic. However, there is progress in terms of technology. Moreover, factors such as hours of operation and percentage of international traffic explain the variations in inefficiency.

Carlucci et al. (2018) analyzed total efficiency, technical and scale efficiency using CCR and BCC models with data of 34 Italian regional airports from 2006 to 2016 . The research also investigated the impact of other factors on efficiency and economic sustainability. Their findings reveal that airport size, cargo traffic, and low-cost carriers are significant variables, together with privatization and deregulation which can benefit airport efficiency.

All those studies were based on the CCR and BCC models; therefore, with a single orientation to input or output. In this work, however, we used a slacks-based model with simultaneous orientation. Suzuki et al. (2012) developed a Distance Friction Minimization (DFM) model as a generalization and extension of the BCC model to obtain a more appropriate configuration of efficiency improvement projection for airports in Europe. DFM does not consider fixing irregular or immutable factors, such as airport runways, as these variables will not change in the short term. Generally, the new methodology indicates a way to reach the efficiency frontier that less affects the airport, with minor reductions of inputs.

Lo Storto (2018) developed a DEA model using meta-frontier concept. Most of public-private partnership (PPP) airports showed higher technical efficiency using data of 45 Italian airports in 2012. The inputs were terminal size, apron size, total runway length, number of employees, 
labor cost and soft opening costs, while the outputs were aviation and non-aviation revenues. Data of passengers, cargo, and movements were used either as input or as output in different model specifications. Three models encompass technical efficiency and revenue efficiency, both output-oriented and cost efficiency as input-oriented.

Adler and Liebert (2014) used a weighted additive slack-based model, input-oriented, considering that managers only have control over operational costs and not on capacities, with minor control over traffic volume in general. The DEA variables included staff costs, operating costs, runway capacity, number of passengers, cargo handled, aircraft movements, and non-aeronautical revenue. For second-stage analysis, they applied a linear regression model, in a robust among - cluster approach, with data combination that concerns ownership structure, economic regulation, level of the potential hub, and local competition. They analyzed the variation of efficiency scores from 1998 to 2007. The policy implications suggested it is better to privatize the airport completely to avoid conflicting objectives in case of partial privatization.

Olfat et al. (2016) used an extension of fuzzy dynamic network SBM DEA with a threepronged approach to add internal functions to the model, factors related to either to passengers, or the community itself. The analysis was made for each node of the airport, community, and passengers in the network of 28 airports. Although using an extension of the slack-based model, this study does not focus on the slacks but only the measured score to compare efficiencies.

Chang et al. (2016) developed a dynamic network DEA framework in the context of US airport financing. The model investigates the substitutability between the two major sources of financing: Passenger Facility Charge (PFC) and Airport Improvement Program (AIP), considering an input-oriented network SBM model, proposed by Tone and Tsutsui $(2010,2014)$ using data of 41 airports from 2009 until 2013. The authors used flight delays as undesirable output, and the following variables: delay (in minutes), cargo handled, enplanement, aircraft operations as outputs and labor cost, material cost, net asset, promotion, PFC, while AIP funds were used as inputs. This study proves that U.S. airports can substitute PFC for AIP funds in the proportion of $8-35 \%$ of the current AIP, but this substitution negatively correlates to productive efficiency.

The network DEA has recent applications in airport analysis (Yu, 2010; Lozano et al., 2013; Wanke, 2013). Yu (2010) applied this method in Taiwanese airports using production and service in the first and second stages respectively, considering number of employees, runway area, apron area and terminal area as inputs. Intermediate variables were runway capacity and terminal capacity, while the outputs were aircraft movements, passenger movement, and cargo volume. Operational efficiency is divided into production and service efficiency, and the latter is divided into landside and airside, considering multi-stages in series and in parallel with environmental factors in the analysis.

Lozano et al. (2013) focused on Spanish airports, with aircraft movement for the first stage and aircraft loading for the second stage. Similarly, Wanke (2013) used the two-stage production process of the Brazilian airports, where the first stage represents their physical infrastructure, and the second stage concerns flight consolidation.

Airport privatization and concession to private management were addressed in Brazil by Fernandes and Pacheco (2018). DEA BCC output-oriented was applied to 60 main airports under INFRAERO administration between 2009 and 2015 - three years before and after concessions began in 2012. The objective was to evaluate the situation of INFRAERO before and after 
concessions and not the performance of airports transferred. Airports under INFRAERO administration showed a loss of market share and declining performance, therefore the company was unable to improve performance in this scenario.

Other methods can be used to assess efficiency. Oum et al.(2006) used a variable factor productivity measure to compute productivity for the major airports in Asia-Pacific, Europe, and North America in 2001-2003. Contrary to expectations, they found strong evidence that airports owned and managed by a mixed enterprise with a government-owned majority is less efficient than $100 \%$ of airports publicly owned and operated.

Oum et al. (2008) applied Stochastic Frontier to explore the relationship between the airport ownership form and its cost efficiency using panel data of the world's major airports. According to results, a $100 \%$ governmental ownership is better than mixed ownership with government majority. These results suggest that countries that consider privatization should keep the majority share of the airport's ownership.

\section{METHODOLOGY}

The DEA technique is used to measure productive efficiency in this study. The Decision-Making Units (DMU) in this research are Brazilian international airports located in state capitals, in addition to other airports with a high movement of passengers and airports that are being considered for concessioning, resulting in a sample of 28 Brazilian airports.

The application of a DEA variant with simultaneous orientation allows the most efficient DMU, which is the one that produces more with fewer resources, an advantageous concept for efficiency measures. However, the use of this model influences the choice of variables in the study and how the proposed variations will be interpreted. An input-oriented model is the best fit to data related to debts and expenses, but this data lacks availability for this sample in a standardized way. Variables related to physical space and infrastructure can identify underused capacities that demand attention, saturated sectors, or even a capacity surplus that can serve a future growth in demand.

According to Gillen (2011), the usual metrics of efficiency do not contribute to information on the optimal size of the airport or a range of optimal sizes, as airports may achieve cost efficiency but may be operating on the wrong scale. In general, the most recurrent variables used as inputs in DEA applications are, in order of frequency: passenger terminal area, number of apron positions, runway length, number of employees, apron area, runway area, parking lots, number of the baggage carousel. The most common outputs are: the number of passengers, the amount of cargo handled, aircraft movement, mail, aeronautical revenue, and non-aeronautical revenue.

Based on the availability of data for the selected airports, the literature review, and the correlation between inputs and outputs, the following input variables were assigned:

- Passenger terminal area $\left(\mathrm{m}^{2}\right)$ (Tsui, 2014): total passenger terminal area, including the area for commercial activities. The total value is the sum of passenger terminal areas when an airport has multiple passenger terminals.

- Total runway length (m) (Jiang et al., 2015): represents the sum of the runway length when an airport has more than one runway.

- Apron area $\left(\mathrm{m}^{2}\right)$ (Lo Storto, 2018): the total apron area includes the passenger apron area, the cargo apron, general aviation apron area, and other aircraft parking areas. 
Inputs related to airport infrastructure are important because airport infrastructure expansion is often impossible in the short-term (Innes and Doucet, 1990), therefore their usage should be optimal and meet future demand. The apron area variable is a general indication to apron capacity, as the number of positions depends on the aircraft size, moreover the total runway length variable can incorporate the number of runways.

Outputs considered in this study were:

- Passenger movement: total passengers carried (embarked and disembarked) in national and international, regular and non-regular flights;

- Cargo handling (t): total air cargo and mail loaded, unloaded and in transit for national and international, regular and non-regular flights;

- Aircraft movements: the total number of aircraft arrivals and departures, national and international, regular and non-regular flights.

Passenger movement is an important factor for airport managers (Suzuki et al., 2003). The outputs selected are the three most recurrent outputs in DEA studies and they are proxies for revenues from aeronautical activities.

The number of variables for a DEA approach is limited depending on the number of DMUs, following the equation (Cooper et al., 2001):

$$
D M U s \geq \max \{m x s, 3(m+s)\}
$$

Data from 28 airports in 2015 were collected from INFRAERO reports and reports of airports granted to concession, available on their official websites. With the collected data, it was possible to evaluate the correlation among the variables. Using the stepwise method (Wagner and Shimshak, 2007), it was determined that the variable 'aircraft movement' did not interfere in the airport efficiency ranking and the score was considered constant without this variable. This variable is also strongly correlated to the other output variables. For these reasons, the variable 'aircraft movement' was removed from the model.

After that, the SBM-DEA model with the formulation of Tone (2001) (equations 1 to 7) was applied to the remaining variables, to obtain the productive efficiency measures of each airport in the sample. Besides evaluating the efficiency score, this paper evaluated the slacks in each variable to enable the airport to reach its efficiency frontier.

The Inverted Frontier was used as a discriminatory tool for the $100 \%$ efficient airports. It consists of a Frontier of Inefficiency calculated by swapping inputs and outputs. A Composite Index is evaluated as the arithmetic mean between the efficiency of the standard frontier and (1 - efficiency on the Inverted frontier) (Soares de Mello et al., 2008). Thereafter, this Composite Index is normalized. This approach distinguishes the most efficient DMU among the ones that form the frontier.

Afterwards, a second stage Tobit regression model was built to identify explanatory variables to the measured efficiency. The use of this method is more suitable than a simple OLS regression because DEA results are truncated from below at once. An innovative idea of this paper is to search for a socio-economic impact on the airport efficiency. This study evaluates the influence of the variables: population in the airport city, GDP per capita, airport site, HDI, Gini Index, and privatization on the efficiency index. The privatization variable was used as a dummy variable.

Tobit estimation in the second stage outperforms parametric methods, estimating the impact of contextual variables on a production correspondence (Banker and Natarajan, 2008). For the Tobit econometric model, variables selected have the latest data available up to 2015 : 
- Population at the airport's city (hab): 2013 estimated data by the Brazilian Institute of Geography and Statistics (IBGE);

- Gross Domestic Product (GDP) per capita (millions R\$): IBGE data from 2012;

- Airport Site (million $\mathrm{m}^{2}$ ): represents the airport size, data from 2015;

- Human Development Index (HDI) of the airport's city: IBGE data from 2010;

- Gini Index of the income per capita: measure of statistical dispersion that represents the income inequality, latest data available from 2010 at Datasus, processed by the Institute of Applied Economic Research (IPEA);

- Privatization as a dummy variable: value 1 if done until 2015.

The effects of socioeconomic variables and privatization on the airport's productive efficiency measure are investigated using the Tobit econometric model. The expected effects of these variables are to investigate the contribution of better socioeconomic indices in the city in the airport's movement (output variables in the DEA model) and indirectly better use of idle facilities. Table 1 shows descriptive statistics for variables.

Table 1 - Descriptive statistics of the variables

\begin{tabular}{|c|c|c|c|c|c|c|c|c|c|c|}
\hline & $\begin{array}{l}\text { Terminal } \\
\left(\mathrm{m}^{2}\right)\end{array}$ & $\begin{array}{l}\text { Runway } \\
\text { (m) }\end{array}$ & $\begin{array}{l}\text { Apron } \\
\text { Area }\left(\mathrm{m}^{2}\right)\end{array}$ & Passengers & Cargo (t) & $\begin{array}{l}\text { Population } \\
\text { (hab) }\end{array}$ & $\begin{array}{l}\text { GDP per } \\
\text { capita } \\
\text { (millions R\$) }\end{array}$ & $\begin{array}{l}\text { Airport Site } \\
\left(\mathrm{m}^{2}\right)\end{array}$ & HDI & $\begin{array}{l}\text { Gini } \\
\text { Index }\end{array}$ \\
\hline Minimum & $1,982.00$ & $1,701.00$ & $17,550.00$ & 347,592 & 577.00 & 63,760 & 8.81 & 6,319 & 0.65 & 0.42 \\
\hline Maximum & $280,000.00$ & $7,180.00$ & $712,895.00$ & $38,985,000$ & $76,084.00$ & $805,400,000$ & 270.51 & $14,050,000,000$ & 0.85 & 0.69 \\
\hline Arithmetic mean & $48,299.02$ & $3,368.80$ & $132,970.60$ & $6,619,573$ & $45,083.96$ & $75,343,483$ & 33.93 & $3,473,784,516$ & 0.76 & 0.58 \\
\hline First Quartile & $7,710.00$ & $2,375.00$ & $41,457.00$ & $1,478,310$ & $3,036.50$ & 435,913 & 14.79 & $8,623,876$ & 0.74 & 0.55 \\
\hline Median & $23,094.01$ & $2,842.50$ & $66,979.00$ & $3,283,223$ & $11,040.50$ & $1,415,000$ & 22.72 & $719,600,000$ & 0.75 & 0.60 \\
\hline Third Quartile & $65,871.75$ & $3,890.75$ & $148,755.75$ & $8,528,072$ & $39,142.00$ & $6,157,500$ & 34.05 & $6,347,750,000$ & 0.79 & 0.63 \\
\hline $\begin{array}{l}\text { Standard } \\
\text { Deviation }\end{array}$ & $63,920.44$ & $1,471.15$ & $157,921.26$ & $8,487,727$ & $93,769.58$ & $183,165,402$ & 48.30 & $4,535,756,235$ & 0.04 & 0.07 \\
\hline
\end{tabular}

\section{RESULTS AND DISCUSSION}

Table 2 shows the airports included in the study. The application of the SBM variant model resulted in 11 efficient airports (39\% of the sample): BSB, CNF, CGH, FLN, GRU, MAO, NVT, PVH, STM, THE, and VCP, considering all five variables. Only four of the efficient airports were privatized until 2015 (BSB, GRU, CNF, VCP). FLN was privatized only in 2017, along with the inefficient ones: POA, SSA, and FOR.

Table 2 shows the efficiency measured by the SBM model for each airport, the relative slacks of each variable, their ranking, and the BCC output-oriented scores for comparison. Among the inefficient units, only CGB, FOR and POA have a score higher than 50\%. Based on the relative slacks, the model suggests a reduction in input variables and an output increase for each DMU to reach the efficient frontier.

CGB has the highest efficiency score among the inefficient ones and the model specifies that to achieve efficiency there should be an increase in cargo handling, although it is considered a benchmark for inefficient DMUs relating to other variables.

Regarding the entire sample, the mean relative slacks in inputs are almost insignificant compared to the mean relative slacks in outputs. Therefore, passenger and cargo movements are the variables with the highest slacks, indicating that these are the variables which need more attention. 
The slack cannot be a fixed goal but an indication of the most detrimental performance variable, from a productive point of view. This consideration is important because the sample is not homogenous and the production processes may differ from each other, e.g. depending on the rate of commercial and aeronautical purposes. Thereby, there are probably no possibilities to decrease or increase variables indicated by slacks, limited to the current structure and economic scenario (Camioto et al., 2017).

Table 2 - Airport efficiency and relative slacks for each variable

\begin{tabular}{|c|c|c|c|c|c|c|c|c|}
\hline & \multicolumn{3}{|c|}{ Efficiency } & \multicolumn{3}{|c|}{ Inputs reduction } & \multicolumn{2}{|c|}{ Outputs increase } \\
\hline & SBM & $\mathrm{BCC}$ & Ranking & Terminal & Runway & Apron & Passengers & Cargo \\
\hline Manaus (MAO) & $100.0 \%$ & $100.0 \%$ & 1 & $0.0 \%$ & $0.0 \%$ & $0.0 \%$ & $0.0 \%$ & $0.0 \%$ \\
\hline Teresina (THE) & $100.0 \%$ & $100.0 \%$ & 1 & $0.0 \%$ & $0.0 \%$ & $0.0 \%$ & $0.0 \%$ & $0.0 \%$ \\
\hline Viracopos (VCP) & $100.0 \%$ & $100.0 \%$ & 1 & $0.0 \%$ & $0.0 \%$ & $0.0 \%$ & $0.0 \%$ & $0.0 \%$ \\
\hline Brasilia (BSB) & $100.0 \%$ & $100.0 \%$ & 1 & $0.0 \%$ & $0.0 \%$ & $0.0 \%$ & $0.0 \%$ & $0.0 \%$ \\
\hline Guarulhos (GRU) & $100.0 \%$ & $100.0 \%$ & 1 & $0.0 \%$ & $0.0 \%$ & $0.0 \%$ & $0.0 \%$ & $0.0 \%$ \\
\hline Porto Velho (PVH) & $100.0 \%$ & $100.0 \%$ & 1 & $0.0 \%$ & $0.0 \%$ & $0.0 \%$ & $0.0 \%$ & $0.0 \%$ \\
\hline Congonhas (CGH) & $100.0 \%$ & $100.0 \%$ & 1 & $0.0 \%$ & $0.0 \%$ & $0.0 \%$ & $0.0 \%$ & $0.0 \%$ \\
\hline Santarém (STM) & $100.0 \%$ & $100.0 \%$ & 1 & $0.0 \%$ & $0.0 \%$ & $0.0 \%$ & $0.0 \%$ & $0.0 \%$ \\
\hline Recife (REC) & $49.5 \%$ & $50.1 \%$ & 5 & $0.0 \%$ & $3.7 \%$ & $0.0 \%$ & $136.7 \%$ & $62.5 \%$ \\
\hline Belém (BEL) & $33.4 \%$ & $37.9 \%$ & 6 & $0.0 \%$ & $44.9 \%$ & $0.0 \%$ & $178.9 \%$ & $129.6 \%$ \\
\hline São Luiz (SLZ) & $31.8 \%$ & $40.3 \%$ & 7 & $0.0 \%$ & $38.1 \%$ & $0.0 \%$ & $63.5 \%$ & $285.8 \%$ \\
\hline Macapá (MCP) & $28.4 \%$ & $37.2 \%$ & 8 & $0.0 \%$ & $0.0 \%$ & $0.0 \%$ & $149.0 \%$ & $354.7 \%$ \\
\hline Curitiba (CWB) & $25.1 \%$ & $31.3 \%$ & 9 & $23.1 \%$ & $9.9 \%$ & $0.0 \%$ & $212.9 \%$ & $296.1 \%$ \\
\hline João Pessoa (JPA) & $22.1 \%$ & $42.6 \%$ & 10 & $0.0 \%$ & $7.6 \%$ & $0.0 \%$ & $54.8 \%$ & $628.5 \%$ \\
\hline Salvador (SSA) & $21.8 \%$ & $37.7 \%$ & 11 & $6.3 \%$ & $26.8 \%$ & $0.0 \%$ & $49.9 \%$ & $567.2 \%$ \\
\hline Rio Branco (RBR) & $20.5 \%$ & $28.1 \%$ & 12 & $0.0 \%$ & $0.0 \%$ & $0.0 \%$ & $233.1 \%$ & $541.7 \%$ \\
\hline Campo Grande (CGR) & $19.7 \%$ & $52.4 \%$ & 13 & $0.0 \%$ & $54.4 \%$ & $21.6 \%$ & $47.3 \%$ & $509.5 \%$ \\
\hline Galeão (GIG) & $16.6 \%$ & $43.5 \%$ & 14 & $31.4 \%$ & $6.7 \%$ & $34.3 \%$ & $130.1 \%$ & $583.3 \%$ \\
\hline
\end{tabular}

Identifying inefficient airports can help decision-making to enhance airport management and also identify airports with underused capacity that can have a higher importance in the air network when hubs are too saturated, as well as an option when an airport is shut down, to enhance the network resilience.

Nonetheless, productive efficiency depends not only on the infrastructure variables analyzed but also on the number of service counters, the number of x-rays, infrastructure for baggage claim, number of employees, loading and unloading equipment for luggage and cargo, platforms, and vehicles for transporting people over apron area.

Among the airports under concession (BSB, CNF, GRU, NAT, GIG, VCP), four of them were efficient, except GIG and NAT that achieved considerably lower efficiencies $(16.6 \%$ and $14.9 \%$ respectively).

The results obtained do not directly imply poor management in airports when the first privatizations had a contractual obligation to develop infrastructure above the demand observed, 
which leads to a capacity surplus and consequently lower productive efficiency (the case of GIG and NAT) and inefficiency in dealing with economic crises. This may indicate problems in the first government concessions and the need for orientation to review current contracts and the next concessions contracts. VCP also had a problem with infrastructure capacity surplus due to contractual obligations that did not meet the real demand. Although VCP is considered efficient in this study, the expansion work continued in the following years.

It can also be observed that small and large airports performed better than medium-sized airports, indicating inadequate management in medium-sized airports, probably due to the lack of benchmarking in this group or their minor role in the air network as saturated airports are prioritized as hubs. This solution would also supplement the idea of operational optimization in airports, since the input reduction proposed by the model could be overcome by an increase in the products, probably because of a rearrangement of routes or other measures.

The aim to identify sectors of poor performance is to help allocate governmental and private resources, e.g. direct to sectors that have no input slacks, indicating a possible limit capacity achieved. Higher input slacks may indicate airports that still have the infrastructure to generate more outputs, based on benchmarks, and new investments can produce outputs at a higher rate than invested, whether the airport operates in crescent returns to scale.

We compared the efficiencies measured with SBM to the output-oriented BCC model (Table 2), frequent in literature. As expected from the literature, efficient DMU in the SBM model was also efficient in the BCC model, however, SBM application reduced inefficient airport scores due to the slacks. For SBM, the efficient unit should have no slack, therefore the optimal quantity of resources and products. The mean efficiency is lower in the SBM application, a more discriminatory variant, and a different efficiency ranking.

Besides, the SBM model indicates changes for each variable to make the DMU reach the frontier, when the BCC model suggests the same increase in all outputs (when output-oriented) or the same reduction to all inputs (when input-oriented). The non-oriented model leads to a new kind of possible users, which considers the possible outputs increase along with the best infrastructure management. This study opens a possibility to use this model in the airport infrastructure, and following studies could introduce variables such as check-in positions, x-ray, baggage belts, exploring an allocative idea.

Due to the number of efficient units, we applied an Inverted Frontier to discriminate these airports. The Composite Index considered that CGH, a public airport, was the most efficient airport considering these variables and SBM model, hence the one able to produce more with its resources, without slacks. The most efficient privatized airport is VCP $\left(4^{\text {th }}\right)$, followed by GRU (8th) and CNF (9th).

CGH is strategically located in São Paulo, the largest business center in Latin America, where many companies and financial institutions are located. CGH is the airport with higher business traffic in Brazil, is located near the city center and serves domestic flights. In 2003, INFRAERO started a renovation plan for the airport complex to meet demand. Nevertheless, the airport operates with its capacity limited, especially related to the runway, besides being the most competitive and saturated airport in Brazil (INFRAERO, 2016).

This paper relates to productive efficiency and not to service level (the perception of quality by the customer), thereby an efficient unit may offer a low level of service to its customers. In 2015 , CWB was considered the airport with the highest quality service perception but achieved an efficiency of $25.1 \%$. 
Furthermore, airport managers should plan at extending the airport's catchment area or focus on new strategies to attract carriers and other business activities to enhance efficiency, particularly cargo activity that represents an important effect in its efficiency (Carlucci et al., 2018).

In order to verify contextual variables that could influence the efficiency measured with the SBM model, we applied a Tobit regression. This application aims to add socioeconomic variables, not used in previous studies. The efficiency value is used as a dependent variable and the independent variables of the best statistical model obtained are population at airports cities, GDP per capita, airport site size, HDI of the city, Gini Index and a dummy variable for airports granted to concession until 2015. Table 3 shows the results of the Tobit model.

Other variables were tested (number of air companies operating in the airport, mean distance between the three closest airports, GDP, vehicle parking slots, passenger capacity per year, mean yield between airports of the sample), but their inclusion resulted in worse statistical goodness-of-fit measures.

Table 3 - Tobit model results

\begin{tabular}{|c|c|c|c|c|c|}
\hline & Coefficient & Standard error & $z$ & p-value & \\
\hline Constant & $-2,1044$ & 1,2563 & $-1,675$ & 0,0939 & * \\
\hline Population 2012 & $-1,5 e-9$ & 0,0015 & $-3,375$ & 0,0007 & $* * *$ \\
\hline GDP per capita & $-0,0019$ & 0,0015 & $-1,288$ & 0,1978 & \\
\hline Airport site & $4,4 e-11$ & $1,6 e-11$ & 2,752 & 0,0059 & $* * *$ \\
\hline $\mathrm{HDI}$ & 5,2093 & 1,8241 & 2,856 & 0,0043 & $* * *$ \\
\hline Gini Index & $-2,1969$ & 1,1149 & $-1,970$ & 0,0488 & $* *$ \\
\hline Privatized until 2015 & 0,0369 & 0,1824 & 0,2021 & 0,8399 & \\
\hline Chi-square & \multicolumn{2}{|c|}{\begin{tabular}{l|l} 
& 15,0726
\end{tabular}} & \multirow{2}{*}{\multicolumn{2}{|c|}{$\begin{array}{l}\text { p-value } \\
\text { ike Criterion }\end{array}$}} & 0,0197 \\
\hline Log of likelihood & \multicolumn{2}{|c|}{$-6,6543$} & \multirow{2}{*}{\multicolumn{2}{|c|}{$\begin{array}{l}\text { ike Criterion } \\
\text {-Quinn Criterion }\end{array}$}} & 29,3087 \\
\hline Schwartz Criterion & \multicolumn{2}{|c|}{39,9663} & & & 32,5669 \\
\hline
\end{tabular}

It was verified that the error follows a normal distribution, with a significant $\mathrm{p}$-value. Note that the variables that present a significant p-value at 5\% are Gini Index, HDI, the size of the airport site, and the population in the airport city. However, the coefficient has a negative value for both the population and Gini Index variables.

There is a statistically significant influence of the socioeconomic level of the city, defined by the HDI and income inequality measured by the Gini Index. Analyzing the coefficients signs, greater efficiency is obtained for cities with higher HDI and lower Gini index, indicating lower income inequality. The size of the airport site is positively related to the greater efficiency measured as they probably have better infrastructure to handle more traffic movement efficiently.

To validate the results, we used the Variance Inflation Factor (VIF) to identify the collinearity problem among variables. The VIF measures how much of the variance in each regression coefficient is inflated when the independent variables are not correlated, identifying multicollinear independent variables (Biagge et al., 2017).

Multicollinearity indicates the exact linear relationship between explanatory variables in a regression model, which may occur due to the data nature or inadequate sampling (Elian, 1998; Gujarati and Porter, 2011). The result was also confirmed by the Belsey-Kuh-Welsch collinearity diagnosis.

Despite having a positive coefficient, the dummy variable for airports granted to concession is not statistically significant, which excludes concession impact in the measured efficiency. 
Some studies suggest that publicly owned airports perform better than privately owned ones (D'Afonso et al., 2015; Merkert and Mangia, 2014; Curi et al., 2010 and Kan Tsui et al., 2014). In other countries, a reason could be the easier availability of public funds, which is not the case in Brazil. Also, joint ownership may be slower in responding to market changes because there is a need to satisfy multiple councils, with different objectives, which leads to lower efficiency (Iyer and Jain, 2019). Moreover, studies show that total concessions may perform better than partial concessions to private management (Iyer and Jain, 2019).

Oum et al. (2006 found no statistical difference in efficiency performance between airports managed by government departments and airports managed by airport authorities. Therefore, contrary to common belief, there is no evidence that airports operated by private sector are more efficient than public corporations or operated by US government branches. The results of this study are consistent with those findings.

As $100 \%$ of public airports are more efficient than PPP airports (Oum et al., 2006), when the objective is private financing, it is relevant for the government to sell a majority stake, although $100 \%$ of private ownership is not more efficient than $100 \%$ of government-owned airports.

Oum et al. (2008) found that privatization of at least one airport in cities with multiple airports would improve their efficiency. Airports owned or controlled mainly by private firms, autonomous public corporations or independent authorities are more efficient than the ones controlled by governmental branch (city/state) or multiple government. Therefore, most of the private and fully publicly owned airports are the most cost-efficient ones, while mixed publicprivate owned airports (especially the ones whose ownership is mainly public) are the least cost-efficient airports (Oum et al., 2008). This may be due to fewer conflicting objectives, as privatized airports seek profit while public airports aim output maximizers (Gillen, 2011). Meanwhile, being the public-private ventures the most inefficient ones, they need further investigation.

Therefore, there is no evidence that privatizations make Brazilian airports more efficient, as there is no statistically significant effect. The results and literature lead to the question from Oum et al. (2006): why have concessions failed to improve efficiency in airports? This question needs further investigation in future studies.

We hereby emphasize that the results obtained are limited to the selected variables, the sample, and the year of the study. It may also be that the gains from privatization take longer to materialize or that they do not even materialize during a crisis, as the contracts were developed for a period of economic growth.

\section{CONCLUSIONS}

DEA is a recognized evaluation method to investigate airport efficiency which does not require productive functions among variables and computes multiple variables of different nature. This paper uses a non-oriented SBM model to improve the discrimination of airports' productive efficiency, not used before in this research field in a non-oriented form, especially in the context of airport privatization. The decision-making units were main Brazilian airports, with variables related to infrastructure, passenger, and cargo movement.

The objective of this article was to evaluate the productive efficiency in the operational aspect and verify if Brazilian airport concessions contribute to higher efficiency, with focus on the variable slacks. Also, the paper aimed to search whether socio-economic variables could influence airport efficiency. 
Only $39 \%$ of the airports sample were considered $100 \%$ efficient in a productive view. Inefficient airports had scores below 50\%, except for CGB, FOR, and POA. Among the privatized airports in the analysis (BSB, GIG, NAT, CNF, GRU, and VCP), four of them were considered efficient, however, GIG and NAT presented low efficiencies (16.6\% and 14.9\%, respectively).

In general, the relative slacks indicated the need for improvement in cargo and passenger traffic to enhance efficiency, with a capacity surplus in infrastructure in terms of productive process. The purpose to use a non-oriented model, which suggests input reduction as a way to reach the efficiency frontier, does not imply in reducing investments in airports, but to identify sectors that need more attention, which may be poorly managed and resources that could generate more products than they currently do.

The results do not directly suggest poor management in airports, as the first privatizations had a contractual obligation to develop infrastructure above the observed demand, leading to lower productive efficiency (the case of GIG and NAT) along with inefficiency to deal with economic crisis. This probably indicates a problem in the first government concessions, therefore the need for orientation to review current contracts and include more realistic terms for the next concessions contracts.

DEA is shown as an effective method that could be used in different ways from the ones in literature. The potential impact of the results is a wider technical and scientific use of the method that could spread its use and interpretation, as well as the capacity to reduce costs and loss of revenue possibly inherited from productive inefficiency, advantage for the companies and the State that receive part of the revenue.

The slacks cannot be interpreted as a fixed goal since the sample is not entirely homogeneous and units can have different production processes. Contrarily, it is possible, within limits, to incentive technology transfer (Camioto et al., 2017) among airports. As CGH can be a reference of practices, airports with the lowest efficiency score and highest slacks demand more attention.

Airport benchmarking identify operational aspects that need more attention, becoming bottlenecks in the process. The presented results to identify strategic points to intervene, sectors that should be an investment priority and surplus in resources for an increase in demand.

This paper also aimed to identify the possible influence of macroeconomic and socioeconomic variables in the measured efficiency. The introduction of socioeconomic variables in this scenario is novel to literature and the results indicate a positive relationship between the efficiency of an airport and its city HDI, and an inverse relation with the Gini Index, representing a low income inequality. The airport site size and the city population are also significant variables.

The slacks analysis, Composite Index and Tobit regression can help to allocate government and private resources to sectors and airports with higher needs in an optimum way. The identified literary gap enables the use of a wide range of variables for future studies, sustainability, financial efficiency, and Brazilian performance worldwide.

As a limitation of this study, DEA application does not enable inference to another sample, results depend on variables and sample used. Adjusting the results interpretation, the novel use of non-oriented DEA can be replicated in other study fields.

The results show that the first privatizations of Brazilian Airports are not considered statistically significant to improve their efficiency and some privatized airports are still inefficient in 
this productive process. Although, other unobserved variables also affect airport efficiency (Oum et al., 2008).

In the same way as Oum et al. (2006) we claim the importance of testing different measurement methodologies before a conclusion to the efficiency effects of privatization and corporatization of airports.

\section{ACKNOWLEDGEMENTS}

This study was financed in part by the Coordination for the Improvement of Higher Education Personnel (CAPES) - Finance Code 001, as well as the National Council for Scientific and Technological Development (CNPq), through MCTIC/CNPq № 28/2018 - Universal: 436236/2018-4.

\section{REFERENCES}

Adler, N.; Liebert, V. (2014) Joint impact of competition, ownership form, and economic regulation on airport performance and pricing. Transportation Research Part A, v. 64, p. 92-109. DOI: 10.1016/j.tra.2014.03.008.

Banker, R.D., Charnes, A. and Cooper, W. W. (1984). Some Models for Estimating Technical and Scale Inefficiencies in Data Envelopment Analysis. Management Science, v. 30, n. 9, p. 1078-1092. DOI: 10.1287/mnsc.30.9.1078.

Banker, R.D., Natarajan, R. (2008). Evaluating contextual variables affecting productivity using data envelopment analysis. Operations Research, v. 56, n. 1, p. 48-58. DOI: 10.1287/opre.1070.0460.

Barros, C. P. (2008). Airports in Argentina: Technical efficiency in the context of an economic crisis. Journal of Air Transport Management, v.14, p. 315-319. DOI: 10.1016/j.jairtraman.2008.08.005.

Barros, C. P., Dieke, P. U. C. (2007). Performance evaluation of Italian airports: A data envelopment analysis. Journal of Air Transport Management, v. 13, p.184-191. DOI: 10.1016/j.jairtraman.2007.03.001.

Bazargan, M., Vasigh, B. (2003). Size versus efficiency: a case study of US commercial airports. Journal of Air Transport Management, v. 9, p. 187-193. DOI: 10.1016/S0969-6997(02)00084-4.

Biagge, M. L. S., Medvid, M. and Assis, C. M. C. (2017). Fator de inflação da variância e regressões auxiliares para diagnóstico do problema de multicolinearidade nos modelos de regressão. XIX Congresso Brasileiro de Engenharia de Avaliações e Perícias, Foz do Iguaçu.

Camioto, F. C., Moralles, H. F., Mariano, E. B., Rebelatto, D. A. N. (2016). Energy efficiency analysis of G7 and BRICS considering total-factor structure. Journal of Cleaner Production, v. 122, p. 67-77. DOI: 10.1016/j.jclepro.2016.02.061.

Camioto, F., Mariano, E. and Rebelatto, D. (2017). Sustainability improvement opportunities in Brazilian sectors: analysis of DEA slacks. Brazilian Journal of Operations \& Production Management, v. 14, n. 3, p. 363-370. DOI: 10.14488/BJOPM.2017.v14.n3.a9.

Carlucci, F., Cira, A., Coccorese, P. (2018). Measuring and Explaining Airport Efficiency and Sustainability: Evidence from Italy. Sustainability, v.10, p. 400. DOI: 10.3390/su10020400.

Chang, Y., Park, H. K., Zou, B., Kafle, N. (2016). Passenger facility charge vs. airport improvement program funds: A dynamic network DEA analysis for U.S. airport financing. Transportation Research Part E, v. 88, p. 76 -93. DOI: 10.1016/j.tre.2016.02.001.

Charnes, A., Cooper, W.W., Rhodes, E. (1978). Measuring the efficiency of decision-making units. European journal of operational research, v. 2, n. 6, p. 429-444. DOI: 10.1016/0377-2217(78)90138-8.

Cooper, W.W., LI, S., Seiford, L.M., Tone, K., Thrall, R.M., Zhu, J. (2001). Sensitivity and stability analysis in DEA: some recent developments. Journal of Productivity Analysis, v. 15, p. 217-246. DOI: 10.1023/A:1011128409257.

Constant, R. S. and Mello, J. C. C. B. S. (2017). Brazilian Electricity Distributors Efficiency Index Based on Non-Radial Efficiency. IEEE Latin American Transactions, v. 15, no. 9, p. 1657-1663. DOI: 10.1109/TLA.2017.8015049.

Curi, C., Gitto, S. and Mancuso, P. (2010). The Italian airport industry in transition: A performance analysis. Journal of Air Transport Management, v. 16, p. 218-221. DOI: 10.1016/j.jairtraman.2009.11.001.

D'Alfonso, T., Daraio, C. and Nastasi, A. (2015). Competition and efficiency in the Italian airport system: New insights from a conditional nonparametric frontier analysis. Transportation Research Part E: Logistics and Transportation Review, v. 80, p. 20-38. DOI: 10.1016/j.tre.2015.05.003.

Elian, S. N. (1988) Análise de Regressão. São Paulo: IME.

Falcão, V. A. and Correia, A. R. (2012). Eficiência portuária: análise das principais metodologias para o caso dos portos brasileiros. Journal of Transport Literature, v. 6, n. 4, p. 133-146. ISSN 2238-1031. (in Portuguese) DOI: 10.1590/S223810312012000400007.

Farrell, M.J. (1957). The measurement of productive efficiency. Journal of the Royal Statistical Society: Series A (General), v. 120, n. 3, p. 253-281. DOI: $10.2307 / 2343100$.

Fernandes, E. and Pacheco, R. R. (2018). Managerial performance of airports in Brazil before and after concessions. Transportation Research Part A: Policy and Practice, v. 118, p. 245-257. DOI: 10.1016/j.tra.2018.09.003.

Gillen, D. (2011). The evolution of airport ownership and governance. Journal of Air Transport Management, v. 17, n. 1, p. 3-13. DOI: 10.1016/j.jairtraman.2010.10.003.

Graham, A. (2011). The objectives and outcomes of airport privatization. Research in Transportation Business \& Management, v. 1, n. 1, p. 3-14. DOI: 10.1016/j.rtbm.2011.05.004. 
Gujarati, D. N. and Porter, D. C. (2011). Econometria Básica. 5a Ed., Porto Alegre: Bookman, 2011.

INFRAERO. (2016) Concessões de Aeroportos. Available in: <http://www.infraero.gov.br/index.php/br/transparencia/concessao.html>. Accessed in: 07/28/2016. in Portuguese)

Innes, J.D. and Doucet, D.H. (1990). Effects of access distance and level of service on airport choice. Journal of Transportation Engineering, v. 116, n. 4, p. 507-516. DOI: 10.1061/(ASCE)0733-947X(1990)116:4(507).

Iyer, K. C. and Jain, S. (2019). Performance measurement of airports using data envelopment analysis: A review of methods and findings. Journal of Air Transport Management, v. 81, p. 101707. DOI: 10.1016/j.jairtraman.2019.101707.

Jiang, Y., Wang L., Wang, C., Zhu, Y. Feng T. and Zheng, S. (2015). Technical efficiency evaluation of alliance airports in China.

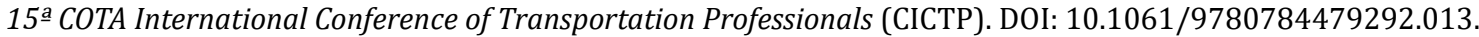

Lo Storto, C. (2018). Ownership structure and the technical, cost, and revenue efficiency of Italian airports. Utilities Policy, v. 50, p. 175-193. DOI: 10.1016/j.jup.2018.01.003.

Lozano, S.; Gutiérrez, E. and Moreno, P. (2013). Network DEA approach to airport performance assessment considering undesirable outputs. Applied Mathematical Modelling, v. 37, n. 4, p. 1665-1676. DOI: 10.1016/j.apm.2012.04.041.

Mariano, E. B., Sobreiro, V. A. and Rebelatto, D. A. N. (2015). Human development and data envelopment analysis: A structured literature review. Omega, v. 54, p. 33-49. DOI: 10.1016/j.omega.2015.01.002.

McDonald, J. F. and Moffitt, R. A. (1980). The uses of Tobit Analysis. The review of economics and statistics, v. 62, n. 2, p. 318321. DOI: $10.2307 / 1924766$.

Merkert, R. and Mangia, L. (2014). Efficiency of Italian and Norwegian airports: A matter of management or the level of competition in remote regions? Transportation Research Part A, v. 62, p. 30-38. DOI: 10.1016/j.tra.2014.02.007.

Olfat, L., Amiri, M., Soufi, J. B. and Pishdar, M. (2016). A dynamic network efficiency measurement of airport performance considering sustainable development concept: A fuzzy dynamic network-DEA approach. Journal of Air Transport Management, v. 57, p. 272-290. DOI: 10.1016/j.jairtraman.2016.08.007.

Oum, T. H., Adler, N., and Yu, C. (2006). Privatization, corporatization, ownership forms, and their effects on the performance of the world's major airports. Journal of Air Transport Management, v. 12, n. 3, p. 109-121. DOI: 10.1016/j.jairtraman.2005.11.003.

Oum, T.H., Yan, J. and Yu, C. (2008). Ownership forms matter for airport efficiency: a stochastic frontier investigation of worldwide airports. Journal of urban economics, v. 64, n. 2, p. 422-435. DOI: 10.1016/j.jue.2008.03.001.

Örkcü, H. H., Balikçi, C., Dogan, M. I. and Genç, A. (2016). An evaluation of the operational efficiency of Turkish airports using data envelopment analysis and the Malmquist productivity index: 2009-2014 case. Transport Policy, v. 48, p. 92-104. DOI: 10.1016/j.tranpol.2016.02.008.

Périco, A. E., Santana, N. B. and Rebelatto, D. A. N. (2017). Eficiência dos aeroportos internacionais brasileiros: uma análise envoltória de dados com bootstrap. Gestão \& Produção, v. 24, n. 2, p. 370-381. DOI: 10.1590/0104-530X1810-15.

Simar, L. and Wilson, P. W. (1998). Sensitivity analysis of efficiency scores: how to bootstrap in nonparametric

frontier models. Management Science, v. 44, n. 1, p. 49-61. DOI: 10.1287/mnsc.44.1.49.

Soares de Mello, J. C. C. B. et al. (2008). DEA Advanced Models for Geometric Evaluation of used Lathes. WSEAS Transactions on Systems, v. 7, n. 5, p. 500-20. DOI: 10.5555/1456007.1456017.

Suzuki, S., Nijkamp, P., Pels, E. and Rietveld P. (2012). Comparative performance analysis of European airports by means of extended data envelopment analysis. Journal of Advanced Transportation, v. 48, n. 3, p. 185-202. DOI: 10.1002/atr.204.

Suzuki, Y., Crum, M.R. and Audino, M.J. (2003). Airport Choice, Leakage, and Experience in Single-Airport Regions. Journal of Transportation Engineering, v. 129, n. 2, p. 212-218. DOI: 10.1061/(ASCE)0733-947X(2003)129:2(212).

Tobin, J. (1958). Estimation of Relationships for Limited Dependent Variables. Econometrica: journal of the Econometric Society, v. 26, n. 1, p. 24-36. DOI: 10.2307/1907382.

Tone, K. and Tsutsui M. (2014). Dynamic DEA with network structure: a slacks-based measure approach. Omega, v. 42, n. 1, p.124-31. DOI: 10.1016/j.omega.2013.04.002.

Tone K. and Tsutsui M. (2010). Network DEA: a slacks-based measure approach. The European Journal of Operational Research, v. 197, n. 1, p. 243-52. DOI: 10.1016/j.ejor.2008.05.027.

Tone, K. (2001). A slacks-based measure of efficiency in data envelopment analysis. The European Journal of Operational Research, v. 130, p. 498-509. DOI: 10.1016/S0377-2217(99)00407-5.

Tsui, K., W. H., Balli, H. O., Gilbey, A. and Gow, H. (2014). Operational efficiency of Asia-Pacific airports. Journal of Air Transport Management, v. 40, p. 16-24. DOI: 10.1016/j.jairtraman.2014.05.003.

Wagner, J. M., and Shimshak, D. G. (2007). Stepwise selection of variables in data envelopment analysis: Procedures and managerial perspectives. European Journal of Operational Research, v. 180, n. 1, p. 57-67. DOI: 10.1016/j.ejor.2006.02.048.

Wanke, P. F. (2013). Physical infrastructure and flight consolidation efficiency drivers in Brazilian airports: a two-stage network-DEA approach. Journal of Air Transport Management, v. 31, p. 1-5. DOI: 10.1016/j.jairtraman.2012.09.001.

Wanke, P. F., Silveira, R. V. and Barros, F. G. (2009). Introdução ao planejamento da infraestrutura e operações portuárias: aplicações de pesquisa operacional. São Paulo: Atlas, 2009. (in Portuguese)

Yu, M. (2010). Assessment of airport performance using the SBM-NDEA model. Omega, v. 38, n. 6, p. 440-452. DOI: 10.1016/j.omega.2009.11.003. 